the damage done by the destruction of a species could be measured economically or not, at least, through his agency, life on this planet had been made less beautiful and less interesting, if not for every. body, at least for many of its human inhabitants.

It may well be that the first seeds of this conviction were sown in Lord Onslow during a period of his early life spent in New Zealand, where his father was Governor, and was one of the first to initiate practical measuras to avert the destruction of New Zealand's unique avi-fauns. The indifference of New Zealanders to the marvellous ecology of which they became the trustees by right of settle. ment always distressed him. Having, as president of the Fauna Society, taken the leading part in securing the adoption of the convention for the Preservation of Wild Life in Africa, he turned eagerly to preparations for a new conference through which he hoped to extend the application of the prineiples embodied in it to south-east Asia and Australasia. That Conference was to have been held under his presidency in 1939 , but the threat of a world war led to its postponement.

Throughout the War, he never lost hope of an active renewal of the campaign for wild-life preservation, which he hoped to see extended ultimately to the whole world. He watched with critical interest the negotiations of the Pan-American Conference in 1940 which led up to the convention for "Nature Protection and Wild Life Preservation in the Western Hemisphere" between the United States and the South American republics. He used unavailingly all the influence he possessed to induce the American States to invite representatives of Canada and other British and European-owned territories in the American Continent to the Conference, and was not a little exasperated by the illogical insularity which led the United States and the rest to exclude them. Nevertheless, he had the satisfaction of observing that the Convention agreed to follow in essentials the model of the African Convention of which he was the legitimate parent, and he was determined that American observers should be invited, for their better education, to the postponed Conference for southeast Asia and Australasia when summoned after the War. He was keenly interested, also, as was to be expected, in the movement for the establishment of national parks and nature reserves in Britain, and was a most active president of the Society for the Promotion of Nature Reserves.

It may be said of Lord Onslow that he saw the light and, very clearly, the vision which the light revealed. In failing health he never lost interest in the work of the Society for the Preservation of Fauna of the Empire, and probably few events gave him greater pleasure than the presentation to him in November last of the first gold medal of the Society in recognition of his outstanding services to the cause of fauna conservation. It will not be easy to find a torch-bearer to succeed him, one who will feed the flame as he fed it, and bear it blazing bright with the same resolute and lofty inspiration.

$$
\text { Hentry G. Mauriot. }
$$

\section{Dr. Hans Przibram}

THE obituary column of The Times records the death "some time in 1944, at Terezin (Theresien. stadt), Czechoslovakia, of Hans Przibram, formerly Professor in the University of Vienns, and his wife Elizabeth Margarethe (née Ruhmann)". Behind these words lies untold tragedy; for Theresienstadt was one of the worst of the concentration camps, and many thousands of Jews were slaughtered there. The War had not long begun when we heard of the death at Dachau of Prof. M. Siedlecki of Cracow, an old and famous and much-loved naturalist; it is scaroely ended when we hear that Hans Przibram has been done to death, who once was rich, enthusiastic, hospitable, and whose Laboratory, or "Vivarium", was known to every naturalist who came to Vienna. We know of many snother, and dread to hear of more, who have suffered from the same ferocious inhumanity.

Hans Przibram began his work about forty years ago, under the influence of Wilhelm Roux, Jacques Loeb and Hans Driesch; in other words, he became a student of experimental zoology. He planned an ambitious work under that title, and brought it out between 1907 and 1914, in five parts, on "Embryogenese", "Regeneration", "Phylogenese", "Vitalität" and "Function". An early paper of his, on the "Anwendung elementärer Mathematik auf biologische Probleme", appeared in Roux's Vortrage in 1908 ; and fifteen years later he published an "Aufbau mathematischer Biologie", in Shaxel's Abhandlungen. Another book of his, published in 1922 after he had become ausserordentlich professor of experimental zoology, was entitled "Form und Formel im Tierreiche", or "Beiträge zu einer quantitativen Biologie". It contains many useful numerical data, physiological and morphological, or "biological constants" as he chose to call them. The new seience of biometry was after his own heart, and he published various "Messungen und Wachstumsmessungen", chiefly among insects. These measurements, especially those on one of the praying mantids, led him to believe (as Brooks and others had suggested before) that the spurts of growth and successive moults of an insect tended to coincide with a doubling of its weight and (presumably) with a histological duplication of every cell in its body; and further, that the doubling of its weight implied a linear increase from one stage to another in the ratio of $1: \sqrt[3]{2}$, or $1: 1 \cdot 26$. The sizes of the successive chambers in a spiral foraminifer should, and do (he said), follow the same law ; but the study of the cast skins, or suecessive moults, of a serpent led to no such result, for no general histo. logical duplication was involved. There was a good deal of truth in all this; but Przibram was apt to go too far, and let his theories outstrip his facts. It is at least clear that he was a keen and early student of that experimental side of zoology which has proved engrossing ever since to many.

Hans had a brother Karl, a distinguished physicist ; we have no news of him. He wrote, among other papers, some on the Brownian movement, which I remember attracting $\operatorname{Sir}$ J. J. Thomson's attention to when they appeared. One was on the Brownian movement of non-spherical bodies, and another (in Pfiligers Archiv) on the Brownian movement as indieated in the movements of minute organisms. He also wrote a curious paper on "Form und Gesch. windigkeit : ein Beitrag zur allgemeine Biologie".

D'Aroy W. Thompson.

WE regret to announce the death of Lord Exmouth, who during 1897-1911 was a member of the chemical staff at Columbia University, on June 7 , aged eighty-two. 